National Planning Institute.

The proposed science policy machinery has received enthusiastic support from amongst others, the science policy secretariat of the United Nations Educational, Scientific and Cultural Organisation (UNESCO), which has been promoting the "minister of science" approach for a number of years.

Others inside the country, however, are less enthusiastic. Despite $\mathrm{Dr}$ Pinilla's promise that the system will "respect the academic autonomy" of individual research institutions, they are worried that attempts will be made to impose unrealistic goals and objectives while limiting flexibility.

Particularly concerned are members of ITINTEC, an agency set up by the government in 1971 to stimulate research in the various areas of productive industry. At present, although working to support areas that have been given priority by the government, ITINTEC is able to operate relatively independently because its main income comes directly from industry.

Under the law establishing ITINTEC, all companies in Peru have to set aside $2 \%$ of their gross profits each year for research. A company can either submit for ITINTEC's approval a research project which it wishes to carry out itself, or hand the money over directly to ITINTEC, which will use it to finance its own research.

The model seems to have worked quite well, and the Venezuelan government is contemplating introducing a similar system (see above). Over a third of ITINTEC's research projects are carried out by universities, and the institute has established centres for wood technology and non-metallic materials, as well as what is claimed to be the best technical information service in Peru.

Furthermore ITINTEC has recently received a $\$ 2$ million grant from the US Agency for International Development to investigate the application of "appropriate technology" ideas to Peru -a project which will include studying the possibility of restoring the famous agricultural terraces built by the Incas, now realised to be a highly efficient means of using soil and rain-fall in mountain areas.

Under the proposed new system. although ITINTEC and other research institutes would remain responsible for developing and carrying out their own research programmes, they would be required to present plans and budgets to the National Council for prior approval. "We feel strongly that technological research and development should be carried out within each sector of industry. without heing subiect to any strong centralised control. which we have been luckv ennugh to avoid in the past." according to Dr

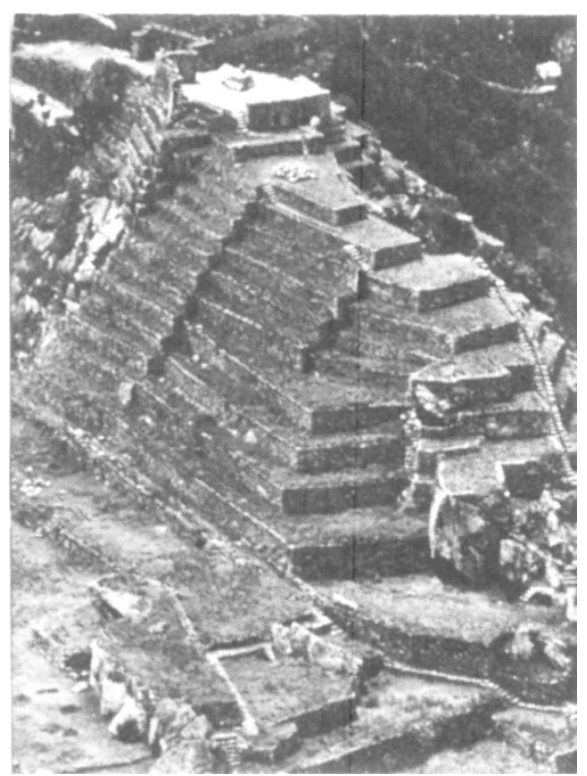

Inca terracing: old but efficient

Jorge Boggio, ITINTEC's director of technology. "Also, although we agree on the need to coordinate the country's scientific and technological research activities, I think it is wrong to give responsibility to a body whose members have had little experience of technological development.

Related views are expressed at the National Planning Institute, which has had a strong influence on carving out Peru's highly nationalistic industrial policy in recent years. "I feel that our country needs a very clear and longterm plan for science and technology, but it must be built on the long-term objectives of socio-economic planning," says the director of the institute's office of research and planning, Dr Fernando Gonzales Vigil. "We need to determine broad priorities first, and then inside these priorities to put an emphasis on specific areas of knowledge, rather than the other way round."

Much will depend on the attitude of the new Minister for Industry, Admiral Jorge Du Bois Gervase, a former head of the industrial service of Peru's navy and therefore, it is claimed. well aware of the problems of relating research to operational nceds.

Another factor will be the effects of the austerity measures that the government has been forced to take to avoid defaulting on its loans from the International Monetarv Fund. Although a pronosal to eliminate industrv's reauired contribution to ITINTEC has been successfully headed off, for example. the institute remains vulnerable.

But whatever the outcome, many feel that the policy finally adopted is likely to be one that increases support for the private sector, and weakens the role of state planners. "This would be the more logical outcome, taking into account the various national and foreign interests," says $\mathrm{Dr}$ Vigil.

\section{Andean Pact propose research tax on 1st world}

Already bidding for a place on the agenda of next year's UNCSTD meeting in Vienna is a proposal that has been put forward jointly by a group of Latin American countries and the Economic Commission for Latin America (ECLA) to establish a new fund for supporting technological development ventures in the Third World.

The countries concerned-Bolivia, Colombia, Ecuador, Peru and Venezuela-are members of the Andean Pact, an economic federation formed in 1969 to harmonise and coordinate the economic and technological policies of its constituent states.

From the beginning, the Andean Pact countries have expressed, mainly through the reports and studies of its secretariat's technical group, the Junta del Acuerdo de Cartagena, fierce criticism of the way that existing technology transfer and patent licensing policies have increased the dependency of the developing on the developed world.

The proposed fund is intended to strengthen the indigenous research and development capacities of developing countries. Contributions would be based on the size of the balance of trade on manufactured goods between rich and poor countries, with the general assumption that the greater the imbalance, the greater will be the technological gap.

Details of the proposals are now being revised in the light of comments made when the idea was discussed at the UNCSTD regional meeting for Latin America in Panama in August. Although doubts were raised by some of the countries present-mostly those claiming to be at an "intermediate" stage of development-others gave it enthusiastic support.

The Pact's position on technology, spelt out in a joint Decision 84 signed in June 1974, is based on the premise that if a country is to have control of its own development programmes. it is not enough merely to control the investment of capital (for example by regulating the financial activities of multinational companies). Equally important is control over the development and use of technology.

"It is easy to show, for example by looking at the way that the patent system has been used, that unless you have people who can control the 


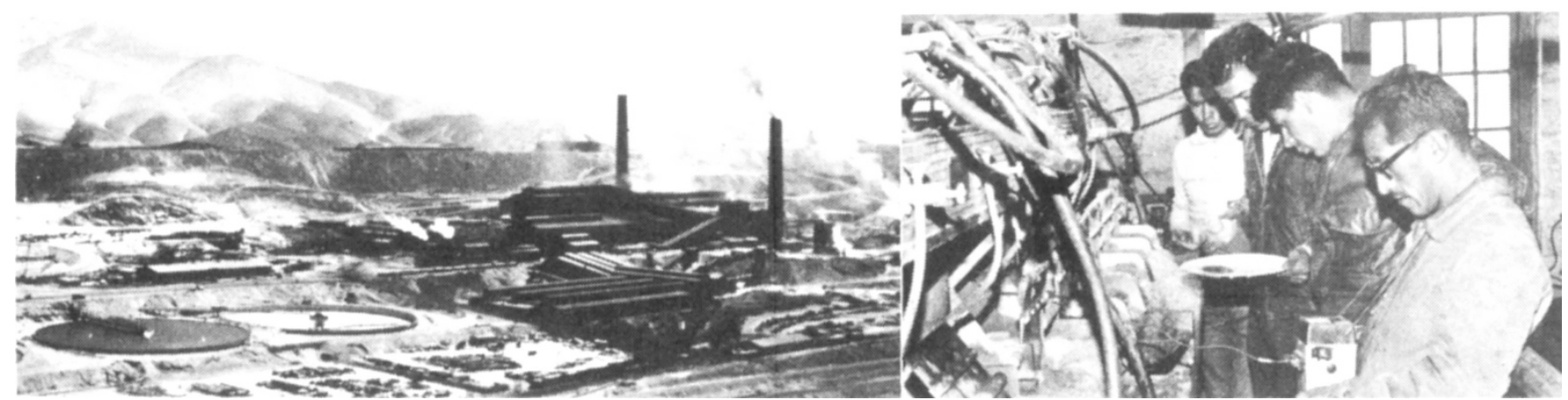

Cooperation to improve production technique. Left: coppermine in Chile. Right: ore analysis in Bolivia.

technology-and not just capital alone -you will remain in a position of dependence on the industrialised nations," says Dr Luis Soto-Krebs, a Chilean metallurgist who is director of the Junta's science and technology policy group.

One paragraph of Decision 84 states that "the high fixed costs of research and development necessitate careful choice of research priorities and the avoidance of duplication of effort". The member countries agreed to develop sub-regional methods for generating new technologies through the application of local knowledge and research, and also to apply these techniques to some pilot projects.

One of the first projects was to improve techniques for copper production, a major source of revenue for Peru, Bolivia, and Chile (which was until 1975 a member of the Andean Pact).

Two problems were tackled simultaneously. The first was to develop new hydrometallurgical techniques for extracting copper from low grade ores; the second was to build up, virtually from scratch in the case of Bolivia, indigenous research and development that would cut down dependence on foreign technology and know-how.

Engineers and scientists from Peru and Bolivia went to Chile-the most advanced of the three in copper technology-for a one-month seminar in 1974 on the theory and laboratorypractice of copper extraction. They also spent some time working in different types of extraction plants in Chile. "The basic idea was that everyone in the project should have a common language; that people in the lab should know about the problems of the plant, and vice versa," said Dr Soto-Krebs.

Members of the Bolivian team, which concentrated on methods of using conventional sulphuric acid leaching of the oxide ores, set to work on the design of a plant planned for the Corocora area by the Bolivian Mining Corporation (COMIBOL) that would process between 300 and 600 tons of ore a day.

Much of the work involved basic geological studies of the site of the plant, and of the properties of the ores-often using testing facilities made available by Peru. Three years' work resulted in detailed plans for what is proudly called "the first Boliviandesigned copper extraction plant" being handed over at the Junta's headquarters in Lima earlier this year.

Officials hope that capital for building the plant will soon be made available, probably by West Germany, which helped to subsidise the initial research and development work. They also point out that the team which drew up the plans now has the experience to tackle other similar projects.

The Peruvians carried out much of their project in a research laboratory set up in La Oroya, the centre of Peru's mining industry. The aim was to investigate ways of exploiting bacteriological leaching techniques for concentrating the ore, already known about by larger copper companies in the US, but little used or understood.

With the help of a German scientist who had been studying the relationship between bacteria and crystal structures, and two Canadian scientists who had been looking at applications of bacteriological leaching, Peruvian brochemists were able to separate out and reproduce those bacteria most suitable to local ores. Starting from ore samples no larger than 300 grams, the research built up until it was able to build and operate a pilot plant. "It soon became clear that we were almost in the front line of this research, and we came out with a method for very fast leaching very different from what was already being done," says Dr Soto-Krebs.

The pilot plant is now producing two tons of copper a day at a considerably lower cost than conventional extraction techniques. Bacterial leaching also has the advantage of being non-polluting-since there are no exhaust gases to discharge into the air-and of being applicable to much lower grade ores than could previously be handled.

Since the success of the two copper projects, two other technological development projects have been set up by the Junta along similar cooperative lines, one studying the use of forest products, a second looking at nutrition and food production. Other projects in the pipeline include a proposal for a joint investigation of techniques for the gasification of coal, of which Venezuela and Colombia in particular have large deposits.

"Too often our people are convinced they can do nothing . . . but we have now convinced people at the highest level that carrying out our own technological development is not a dream, and that investing in the generation of such technology is not useless," says Dr Soto-Krebs.

Financing for similar types of projects could, it is claimed, be provided by the new fund which is being suggested to UNCSTD. The idea for such a fund was first raised at a meeting in Caracas earlier this year by $\mathrm{Dr}$ Francisco Sagasti, the Perurian coordinator of a five-year study of science and technology policy in Latin America that has been financed by Canada's IRDC.

"One area of top priority in stimulating cooperative research ventures between developing countries is providing financial support," says Dr Sagasti. "What is being suggested is that the developed countries make available a sum proportional to the imbalance in trade in manufactured goods with the developing nations, calculated on a regional basis."

Dr Sagasti estimates that, using 1977 trade figures and calculating on the basis of 0.25 per cent of the trade imbalance in manufactured goods, Latin American countries would receive about 60 million from the USA, Japan and members of the EEC alone.

"Such a mechanism would help to increase significantly the flow of funds for scientific and technological activities in the Third World, thus initiating a gradual process of redistribution of the world science and technological effort," said Dr Sagasti.

NEXT WEEK : a report by David Dickson on the role of the scientists in Brazil in criticising Brazilian energy policy; and environmental research in the Amazon 